\title{
EFFECTS OF HIGH PRESSURE GASES ON THE MOTILITY AND FERTILIZING CAPACITY OF AVIAN SPERMATOZOA STORED IN VITRO
}

\author{
F. G. PROUDFOOT \\ Research Station, Canada Department of Agriculture, \\ Kentville, Nova Scotia
}

(Received 29th October 1971, accepted 20th March 1972)

\begin{abstract}
Summary. The motility and fertilizing capacity of avian spermatozoa were enhanced when stored under gaseous air or nitrogen at 21 atm for $7 \mathrm{hr}$ at $11^{\circ} \mathrm{C}$. Fertilizing capacity was totally destroyed when semen was stored under gaseous oxygen or carbon dioxide at $21 \mathrm{~atm}$ for $7 \mathrm{hr}$ at $11^{\circ} \mathrm{G}$.
\end{abstract}

\section{INTRODUGTION}

Proudfoot (1966) demonstrated that the viability of spermatozoa was superior when they were stored in oxygen rather than in air, carbon dioxide or nitrogen. Further evidence was presented by Proudfoot \& Stewart (1967) that the fertilizing capacity of fowl spermatozoa, kept for $17 \mathrm{hr}$ at $10^{\circ} \mathrm{C}$, was enhanced by storage in an atmosphere of oxygen.

The present work was undertaken to evaluate the effect on the fertilizing capacity and motility of fowl spermatozoa when subjected to air, oxygen, nitrogen or carbon dioxide under $21 \mathrm{~atm}$ for $7 \mathrm{hr}$ at $11^{\circ} \mathrm{C}$.

\section{MATERIALS AND METHODS}

Leghorn males and females, of about 1 year of age when the experiment commenced, were used. Males were handled and semen collected for 3 consecutive days before the experiments were started. For all subsequent work, the semen collected the day after a period of rest was discarded before collecting semen for experimental work. The semen collection and insemination techniques were the same as those reported by Proudfoot \& Stewart (1967). Approximately $5 \mathrm{~min}$ elapsed during the collection of semen from twelve males. The semen was pooled and stirred gently and $0.4 \mathrm{ml}$, approximately equivalent to a single ejaculate, was dispensed into each of two vials. One vial was then placed in a specially constructed pressure chamber for exposure to air, carbon dioxide, nitrogen or oxygen. The pressure used was $21 \mathrm{~atm}$ (absolute), and was increased at the rate of $3 \mathrm{~atm} / \mathrm{min}$. The holding time was $7 \mathrm{hr}$. Pressure was released at the rate of $2 \mathrm{~atm} / \mathrm{min}$. This procedure was repeated on 4 consecutive days each week in each experiment. 
In Exp. 1, semen was stored for $7 \mathrm{hr}$ in two holding environments (1) in the high pressure unit at $21 \mathrm{~atm}$ (absolute) and (2) in air by placing an open $6 \cdot 8-\mathrm{ml}$ plastic vial containing the semen inside a $18 \cdot 7-\mathrm{ml}$ plastic vial capped at atmospheric pressure. The atmospheric volume was equivalent in both storage environments. After storage, the semen was stirred gently before insemination. Each sample was inseminated into five to eight females using $0.05 \mathrm{ml}$ semen per female (Taneja \& Gowe, 1962), a total of twenty-five birds being inseminated per group in Exp. 1.

The same general storage procedure was followed in Exps 2, 3 and 4 with semen stored in air at atmospheric pressure compared with storage in nitrogen, oxygen and carbon dioxide, respectively, at 21 atm absolute.

The apparatus for exposing semen to high gaseous pressures was specially designed. Gas from a storage cylinder was admitted to a brass cylinder through an inlet needle valve and then flowed through the cylinder to the atmosphere

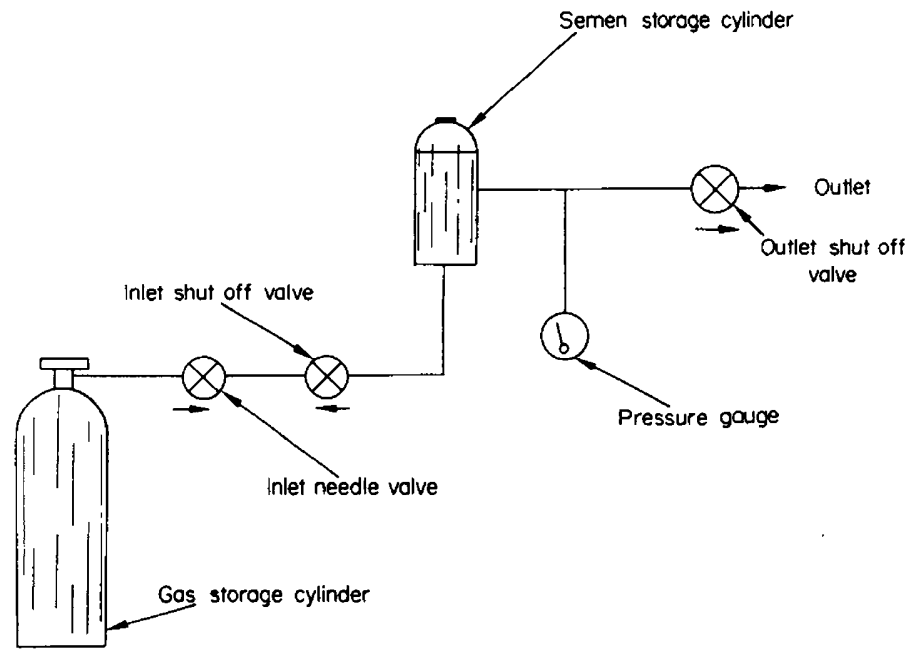

TeXT-FIG. 1. Schematic diagram of gas pressurizing system.

through an outlet shut-off valve (Text-fig. 1). When the outlet valve was closed, pressure in the cylinder built up at a rate controlled by the inlet needle valve. When operating, the tube containing semen was placed in the chamber and sealed by the use of a teflon gasket and locking screw. Inlet and outlet valves were opened and gas to be used was flushed through the chamber; the outlet valve was then closed and the needle valve was opened gradually to increase gaseous pressure at the desired rate. When the required pressure was achieved, the cylinder was disconnected so that pressure was released through the needle valve at the desired rate at the end of the storage period.

Fertility was measured by incubating eggs for 3 to 5 days, and then breaking them to examine for embryonic development.

Sperm motility was determined microscopically on two separate readings for each comparison using rating 0 to 5 , where $0=$ no motility and $5=$ maximum motility. Semen samples were warmed in a water bath for $5 \mathrm{~min}$ at $37^{\circ} \mathrm{C}$ before microscopical examination at room temperature $\left(21^{\circ} \mathrm{C}\right)$ for motility. 


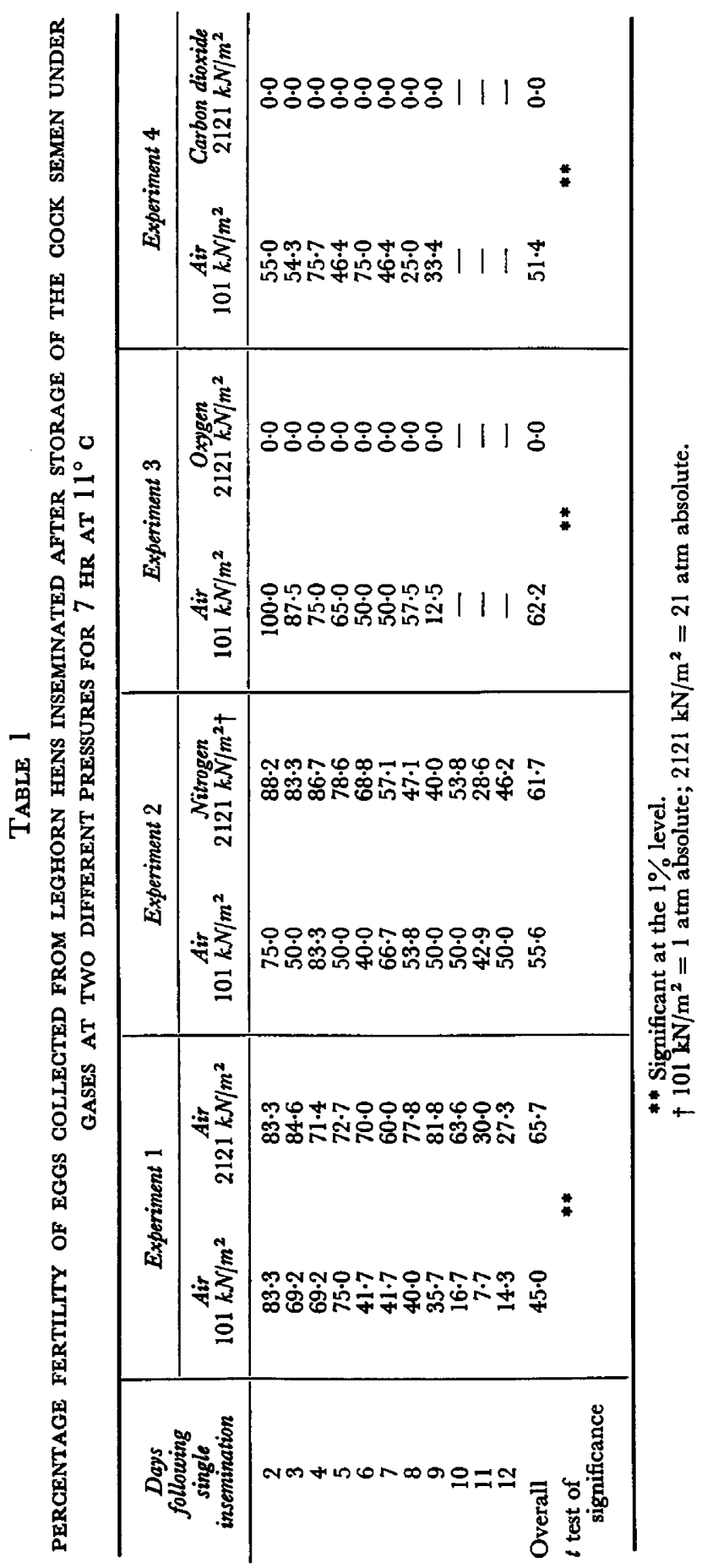




\section{RESULTS}

Storage of semen at $21 \mathrm{~atm}$ for $7 \mathrm{hr}$ at $11^{\circ} \mathrm{C}$ in either carbon dioxide or oxygen totally destroyed the fertilizing capacity of the spermatozoa (Table 1). No detrimental effect occurred on the semen stored in either air or nitrogen at 21 atm. Fertility was significantly higher for semen stored in air at $21 \mathrm{~atm}$ than for semen stored in air at atmospheric pressure.

During the initial 5-day egg collection period, fertility was significantly higher for semen stored in nitrogen at 21 atm than for semen stored in air at atmospheric pressure. However, this difference was not significant when the egg collection period was extended to 12 days following insemination.

The time lapse during depressurizing did not appear to be critical as similar results were obtained when the pressure was released over a 15-min period compared with a 5-min initial pressure release time.

It was observed that following depressurization of carbon dioxide, a distinct effervescence of the semen occurred. This effervescence was reduced when the depressurizing time was extended from 5 to $15 \mathrm{~min}$. Effervescence did not occur following depressurization of the oxygen, air or nitrogen gaseous environments.

TABLE 2

SPERM MOTILITY RATING AFTER STORAGE OF LEGHORN COCK SEMEN UNDER DIFFERENT GASEOUS PRESSURES FOR 7 HR AT $11^{\circ} \mathrm{C}$

\begin{tabular}{l|c|c}
\hline \multicolumn{1}{c|}{ Treatment (gas) } & Pressure $\left(\mathrm{kN} / \mathrm{m}^{2}\right)^{*}$ & Rating \\
\hline Air & 101 & $1 \cdot 5$ \\
& 2121 & $4 \cdot 0$ \\
Oxygen & 101 & $2 \cdot 0$ \\
& 2121 & $0 \cdot 0$ \\
Carbon dioxide & 101 & $3 \cdot 0$ \\
Nitrogen & 2121 & $0 \cdot 0$ \\
& 101 & $0 \cdot 5$ \\
& 2121 & $4 \cdot 0$ \\
\hline
\end{tabular}

$* 101 \mathrm{kN} / \mathrm{m}^{2}=1$ atm absolute; $2121 \mathrm{kN} / \mathrm{m}^{2}=21 \mathrm{~atm}$ absolute.

\section{DISCUSSION}

Proudfoot \& Stewart (1967) reported a beneficial effect of storing semen in oxygen at atmospheric pressure. It was assumed that oxygen was beneficial in the support of the endogenous metabolism of spermatozoa (Goldberg \& Norman, 1961). This theory is further supported by the significantly higher fertilizing capacity of spermatozoa stored under air at 21 atm since the latter would produce a higher concentration of oxygen over the semen surface, thereby promoting the oxidative processes associated with sperm metabolism. However, oxygen at $21 \mathrm{~atm}$ has an adverse effect on fertilizing capacity and the toxic effect of oxygen on biological tissues has been reported by a number of researchers including Watari, Hishizawa \& Matsudaira (1967) and Straub (1967). An 
optimum oxygen tension, therefore, exists which is beneficial to the fertilizing capacity of semen held in vitro at $11^{\circ} \mathrm{C}$ for $7 \mathrm{hr}$.

Anaerobic metabolism probably occurred in the pressurized nitrogen gaseous environment. However, viability is apparently enhanced by the pressure itself since, as reported earlier by Proudfoot (1966), nitrogen at atmospheric pressure exhibited an adverse effect on fertilizing capacity.

The motility scores presented in Table 2 provide further evidence regarding the viability of spermatozoa when exposed to the different gases at both $1 \mathrm{~atm}$ and $21 \mathrm{~atm}$. The high motility scores of 4.0 for both air and nitrogen at $21 \mathrm{~atm}$ correspond to the overall fertility of $66.4 \%$ and $61.9 \%$, respectively (Tables 1 and 2). These data also illustrate the inverse relationship of different gaseous environments at atmospheric pressure versus 21 atm.

It is concluded that the pressurization of an air or nitrogen gaseous environment to $21 \mathrm{~atm}$ enhanced the fertilizing capacity of avian spermatozoa when stored for $7 \mathrm{hr}$ at $11^{\circ} \mathrm{C}$. A similar pressurization of an oxygen or carbon dioxide gaseous environment totally destroyed the fertilizing capacity of the semen.

\section{AGKNOWLEDGMENT}

Appreciation is expressed to Peter W. Voisey, Engineering Research Service, Research Branch, Canada Department of Agriculture, Ottawa, for the design and construction of the High Pressure gaseous system used in these experiments.

\section{REFERENGES}

Goldberg, E. \& Norman, C. (1961) The metabolism of ejaculated spermatozoa from the fowl. F. cell. comp. Physiol. 58, 175.

Proudfoot, F. G. (1966) The influence of oxygen and other gases on the fertilizing ability of fowl semen held several hours at $10^{\circ} \mathrm{C}$ in Cryovac enclosures. Poultry Sci. 45, 443.

Proudfoot, F. G. \& Stewart, D. K. R. (1967) The effect of oxygen and type of container on the retention of the fertilizing capacity of fowl spermatozoa stored in vitro. 7 . Reprod. Fert. 13, 251.

STRAud, J. P. (1967) Mechanism of the toxic effects of hyperbaric oxygen. Nature, Lond. 215, 1196.

TANEJA, G. C. \& GowE, R. S. (1962) Effect of varying doses of undiluted semen on fertility and hatchability in the domestic fowl. 7. Reprod. Fert. 4, 161.

Watari, T., Hishizawa, T. \& Matsudaira, H. (1967) Changes in nucleic acid metabolism of tumour cells under high pressure oxygen. Nature, Lond. 215, 1378. 